\title{
Smartphone Use and Multitasking Behaviour in a Teacher Education Program (TEP)
}

\author{
https://doi.org/10.3991/ijim.v12i2.7345 \\ Ade Hikmat( $\left.{ }^{\varpi}\right)$, Herri Mulyono \\ University of Muhammadiyah Prof. DR. HAMKA, Indonesia \\ Ade_hikmat@uhamka.ac.id
}

\begin{abstract}
This paper reports on a small scale investigation into preservice teachers' multitasking behaviours during a course in a teacher education program (TED). Specifically, it addresses three research questions, 1) how frequent do preservice teachers do multitasks with smartphone, 2) what are the types of preservice teachers' multitasking behaviour, and 3) to what extent does multitasking behaviour affect preservice teachers' learning. To this end, we did a classroom observation where smartphone was used to facilitate learning. During the observation, we wrote notes concerning preservice teachers' multitasking behaviour with their smartphone. In addition, a total of 35 preservice teachers was surveyed. Findings of this study show that $97.14 \%$ of preservice teachers do multitasking in class; although the frequency and types of multitasking with smartphone vary. The findings also highlight fifteen types of multitasking behaviour with two most common activities: texting and searching. The analysis of preservice teachers' responses on the survey as well as the observation data suggest that multitasking behaviour contributes both positively and negatively to preservice teachers' learning. In reference to the findings, implications of the study to TEP are offered.
\end{abstract}

Keywords - multitasking behaviour, mobile learning, smartphone, teacher education

\section{Introduction}

Recent advancement of smartphone features and applications which integrates the internet technology nowadays has enabled people to communicate and share information with each other in variety of forms such a telephone call, text messaging, email, chat application, video conference, personal blogs and etc. In addition, as "a mini computer" smartphone can function as digital media players that allow its user to play music, videos, creating and modifying photos, sounds and videos on a single interface. Multitasking with smartphone is inevitable as people are continuously exposed by a considerable amount of features and applications on their smartphone.

Multitasking is simply viewed as "doing more than one activity simultaneously" [1, p. 366]. Junco [2, p. 2237] provides a comprehensive view of multitasking, defining it as "divided attention and non-sequential task switching for ill-defined tasks as 
they are performed in learning situations". Multitasking with smartphone in learning in this article is thus understood as "as both divided attention and rapid task switching between learning and off-task mobile phone use" [3, p. 34].

In classroom, the incorporation of smartphone to support students learning and the students multitasking behaviour with such a technology are recent phenomena that may have impact on students learning [4]. Chen and Yan [3] suggest that students' multitasking behaviour with smartphone in classroom learning has widely been considered as primary source of distraction on their learning performance. Students who have smartphone and bring this kind technology into classroom learning tends to do irrelevant tasks (multitasking) which eventually result on impairment of their own learning [3][5]. Burak [6], for example, surveyed 774 university students concerning their multitasking behaviours in class. The result shows that students who engage in classroom multitasking are significantly related lower achievement in GPA and are potential to the increase of risk behaviours.

The use of smartphone to support learning in classrooms has widely discussed in literature in teacher education context, among others Baran [7], Price at al. [8], Şad and Göktaş [9], Seppälä and Alamäki [10] and Serin [11]. The primary focus of this body of literature is on the use mobile technology and how this kind of technology was used in context of teacher education e.g. see Seppälä and Alamäki [10]. While multitasking behaviours recently have been critical issues on smartphone use in higher education [4][6][12]-[14], this kind of behaviour is underexplored in the content of teacher education. It is thus the aim of this paper to explore the preservice teachers' multitasking behaviours with smartphone in a course in teacher education program (TEP). Three research questions are addressed as follow:

1. How frequent do preservice teachers do multitasks with smartphone?

2. What are the types of preservice teachers' multitasking behaviour?

3. To what extent does multitasking behaviour affect preservice teachers' learning?

\section{Method}

\subsection{Setting and the participants.}

This present study was aimed to examine the frequency of preservice teachers' multitasking behaviour during learning courses, types of their multitasking behaviour and the extent to which multitasking affect their learning. A total of 35 preservice teachers taking a course in a teacher education program (TEP) in a private university in Jakarta, Indonesia participated. They were two males and thirty three females.

In the course, smartphone was purposefully incorporated as a technology to support our instruction as well as students' learning. Particularly, the objectives of smartphone use in the courses were twofold: First, it was to facilitate reading activity which was carried out in hybrid modes of delivery, that is in-classroom reading and out of the classroom reading session see [15] [16]. A week before the classroom session, we asked the students to download learning materials that available online in the University website. As the learning portal was private, students were required to use 
their university account to access into the University database and download the materials. They were also told to store and keep the files into their smartphone to ease the students to retrieve and read the learning materials.

Second, smartphone was used for learning resources. During a classroom discussion, we asked the students to search for certain information from the internet using their smartphone. For example, we asked our students to identify some countries with low-context communicators. In this activity, the students were asked to use their smartphone to search for more information about countries whose people were lowcontext communicators. Furthermore, smartphone was also functioned to help us distribute classroom assignment. To this end, we created online assignments on the University's learning web portal. We asked our students to complete the assignment online with their smartphones.

Prior to the courses, we surveyed the students if the students had smartphones and level of skill they possessed to operate smartphones. From the survey, it was found that all students had smartphone and almost all (97.14\%) brought their phones to classroom. Students also reported that they had used smartphone not only as a communication tool, but also as entertainment, and learning resources. Our students were also able to download and install certain applications from 'Play Store' in addition to their basic browsing skills such as searching for certain information on web with smartphone, uploading files, sharing files, downloading files and storing the files into the smartphone memory.

\subsection{Reflective teaching}

Reflective teaching which is viewed as teachers and student teachers' examination of "their attitudes, beliefs, assumptions, and teaching practices" Richards and Lockhart, 1994 as cited in Bailey and Springer [17, p. 106] plays a significant role in teachers' professional development activities [18]-[21]. Many authors such as Bailey and Springer [17] and Farrell [21] viewed that innovations in classroom teaching and learning practices are promoted through reflection and reflective practises. Innovation in their view is perceived as changes in "pedagogical materials, approaches, and values" Marke, 1993 cited in [17, p. 107]. Through reflections, teachers are given opportunities to learn from their past-teaching practices, from their students and from their classroom interaction during the classroom interaction [15] and accordingly they employ the obtained knowledge to improve their classroom instructions practices [17][21]. In our context, we introspected our classroom practice within which smartphone was used to support our instructional activity and, more importantly, our students' learning. Specifically, we examined students' multitasking behaviours when utilising the smartphone and whether such behaviours benefited their learning.

\subsection{Data collection and analysis}

The data of the present study were gathered through classroom observation and student survey. The student survey included students' self-reported use of smartphone during a learning course and was distributed to 35 preservice teachers once after a 
mid-term course exam. The survey comprised of sixteen closed-ended questions and two open-ended questions. In total, there were eighteen questions asked to the students. The data gathered from this student survey then were analysed quantitatively using descriptive statistics using a percentage.

In addition to the survey, the data were gathered from classroom observation. In our reflective practice, classroom observation was perceived to provide us with a holistic view of classroom practice which accordingly enabled us understand the instructional practices within a realistic environment [22]. In conducting classroom observation, we observed students' activity with smartphone during the classroom instruction with a focus on students' multitasking behaviours with smartphone. We wrote an observation note and reflective journals. The data gathered from the observation were analysed using content analysis as suggested by Rayford [23].

\section{$3 \quad$ Findings and Discussion}

In this section, findings and discussion from our study are structured based themes as below:

\subsection{Preservice teachers' use of smartphone in classroom}

Smartphone seems to be the most electronic device that preservice teachers used in their daily routine. Result from the survey showed that all preservice teacher participants accessed their smartphone regularly; although total hours spent among the participants were vary. Almost half (42.86\%) mentioned that they used smartphone more than 10 hours a day, $28.57 \%$ was between three to five hours a day, $17.14 \%$ accessed every one hour, $11.47 \%$ was every ten minutes or less. This condition unlikely occurred in classroom where many of the preservice teachers said that they rarely accessed their smartphone ( $48.57 \%$ seldom use, 14.29 very seldom). Some others mentioned that made use of their smartphone while learning (34.29\% frequent, $2.86 \%$ most frequent).

When preservice teachers were asked about the reasons for their use of smartphone, many of them $(51.43 \%)$ said that it was to support their learning, $28.57 \%$ mentioned to get rid of boredom, $2.86 \%$ due to inevitable reason, and other reasons (17.14\%). Preservice teachers' activities with smartphone during classroom learning are presented in the following Table 1 and the details of activity types and applications used are described inTable 2. Interestingly, these multitasking activities seems typical among university students e.g. see Junco and Cotton [12] and Puente[14] .

The survey results as described in Table 2 was quite surprising to us. Despite the fact that the smartphone use was aimed to support learning in the classroom as had planned before the course, it was found that preservice teachers' activity of texting and searching remained higher compared to their activity of reading electronic textbooks and other relevant learning materials. As shown in Table 2, nearly half of preservice multitasking in classroom activity concerned with texting (41.57\%). Some texting application mentioned by the preservice teachers included the use of short text 
Table 1. Preservice teachers' activity with smartphone

\begin{tabular}{|l|c|c|c|c|c|}
\hline \multicolumn{1}{|c|}{ Activity with Smartphone } & $\begin{array}{c}\text { Most frequent } \\
\mathbf{\%}\end{array}$ & $\begin{array}{c}\text { Frequent } \\
\mathbf{\%}\end{array}$ & $\begin{array}{c}\text { Seldom } \\
\mathbf{\%}\end{array}$ & $\begin{array}{c}\text { Very Seldom } \\
\mathbf{\%}\end{array}$ & $\begin{array}{c}\text { Never } \\
\mathbf{\%}\end{array}$ \\
\hline To support learning & 5.7 & 54.29 & 31.43 & 8.57 & 0 \\
\hline To make a telephone call & 0 & 2.87 & 11.47 & 25.71 & 60 \\
\hline Texting & 8.57 & 42.86 & 34.29 & 11.43 & 2.86 \\
\hline To access email & 0 & 22.86 & 48.57 & 14.29 & 14.29 \\
\hline To access Facebook & 2.86 & 0 & 11.43 & 25.71 & 60 \\
\hline To search for information & 17.14 & 62.86 & 20 & 0 & 0 \\
\hline $\begin{array}{l}\text { For entertainment (music, online news } \\
\text { etc.) }\end{array}$ & 2.86 & 42.86 & 34.29 & 11.43 & 8.57 \\
\hline
\end{tabular}

Table 2. Smartphone activity and applications used by preservice teachers during a course in a teacher education program (TEP)

\begin{tabular}{|c|c|c|c|}
\hline Activities & Occurance & $\begin{array}{c}\text { Percentage } \\
\% \\
\end{array}$ & Application used \\
\hline Texting & 37 & 41.57 & $\begin{array}{l}\text { Short text message service } \\
\text { (SMS), Whatsapp (WA), Line, } \\
\text { Twitter, and Blackberry Messen- } \\
\text { ger (BBM) }\end{array}$ \\
\hline $\begin{array}{l}\text { Searching } \\
\text { Searching (general) } \\
\text { Searching relevant learning materials }\end{array}$ & $\begin{array}{c}30 \\
1\end{array}$ & $\begin{array}{c}33.71 \\
1.12\end{array}$ & Web Browser, Chrome, Safari \\
\hline Accessing Instagram & 3 & 3.37 & Instagram \\
\hline Accessing Facebook & 1 & 1.12 & Facebook \\
\hline $\begin{array}{l}\text { Reading } \\
\text { Reading electronic book (e-book) } \\
\text { Reading relevant learning materials } \\
\text { Reading irrelevant materials }\end{array}$ & $\begin{array}{l}4 \\
1 \\
3\end{array}$ & $\begin{array}{l}4.49 \\
1.12 \\
3.37\end{array}$ & $\begin{array}{l}\text { PDF Reader } \\
\text { Webpages }\end{array}$ \\
\hline Sending Email & 1 & 1.12 & Gmail, Yahoo \\
\hline Recording lectures & 1 & 1.12 & Voice recorder \\
\hline Electronic Dictionary & 4 & 4.49 & Kamus \\
\hline Translating language (electronic translator) & 1 & 1.12 & Google Translate, Translator \\
\hline Listening to music & 2 & 2.25 & Multimedia player \\
\hline Total activity (occurence) & 89 & 100 & \\
\hline
\end{tabular}

message service (SMS), Whatsapp (WA), Line, Twitter, and Blackberry Messenger (BBM). Preservice teachers were also shown to obtain information from online through web-searching (33.71\%), although only $1.12 \%$ was specifically aimed to find information relevant to their learning. Moreover, preservice teachers seemed reluctant to use smartphone to facilitate reading activity through digital applications on the smartphone (4.49\%) and to use digital dictionary or translator to help with English vocabulary during classroom learning. This finding indicated that the use of smartphone in classroom is unlikely effective as it did not facilitate preservice teachers' learning activity as expected before classroom practice. 


\subsection{Types of preservice teachers' multitasking behaviour with smartphone in classroom}

Preservice multitasking behaviours seems apparent in this study. Findings from the survey have showed a number of activity preservice teachers had done simultaneously with their smartphone. It was found that $45.71 \%$ preservice teachers frequently conducted multitasking, $42.68 \%$ were seldom, $8.57 \%$ very seldom, and other $2.86 \%$ never. When asked about what applications they accessed in their smartphone and what the activities were, preservice teachers responded differently. Those mentioned that they did conduct multitasking said that they accessed two applications simultaneously when using smartphone (42.86\%), 34.43\% accessed three applications, $14.29 \%$ accessed four applications, $5.71 \%$ accessed more than four applications, and other $5.71 \%$ did not respond. Table 3 shows fifteen types of multitasking behaviours that preservice teachers had done with their smartphone during our classroom practice and the connection among multitasking activities with each other are presented in Fig. 1.

As shown in Table 3, texting and searching have shown to be the two most prominent activities in preservice teachers' multitasking behaviours with smartphone in classroom learning. Students' activity of texting, for example, was frequently done simultaneously with other activities such as doing Instagram and Facebook, websearching, listening to music, using electronic dictionary and reading activity. While the other searching activity was primary done together with other activities such as doing Instagram, using electronic dictionary and reading. This finding is interesting but not surprising as finding of a study by Tindell and Bohlander [24] has showed $92 \%$ of their university students did texting during classroom learning. However, one of our primary concerns about the preservice teachers' texting behaviour during class

Table 3. Types of preservice teachers' multitasking behaviours

\begin{tabular}{|c|c|c|c|}
\hline Code & Multitasking Behaviours & Code & Multitasking Behaviour \\
\hline A & Texting + searching & I & $\begin{array}{l}\text { Texting }+ \text { searching }+ \text { reading textbooks }+ \\
\text { email }\end{array}$ \\
\hline $\mathrm{B}$ & Texting + searching relevant learning materials & $\mathrm{J}$ & Texting + dictionary + reading textbooks \\
\hline $\mathrm{C}$ & Texting + accessing Instagram + searching & $\mathrm{K}$ & Texting + searching + accessing Facebook \\
\hline $\mathrm{D}$ & Texting + accessing Instagram & $\mathrm{L}$ & $\begin{array}{l}\text { Texting }+ \text { searching }+ \text { reading irrelevant } \\
\text { materials }\end{array}$ \\
\hline $\mathrm{E}$ & Texting + searching + listening to music & M & $\begin{array}{l}\text { Searching relevant learning materials }+ \\
\text { electronic dictionary }+ \text { electronic translator }\end{array}$ \\
\hline $\mathrm{F}$ & Recording lectures + reading textbooks & $\mathrm{N}$ & Texting + searching + reading textbooks \\
\hline G & Texting + reading relevant learning materials & $\mathrm{O}$ & Texting + electronic dictionary + searching \\
\hline $\mathrm{H}$ & $\begin{array}{l}\text { Electronic dictionary }+ \text { searching }+ \text { reading } \\
\text { textbooks }\end{array}$ & & \\
\hline
\end{tabular}




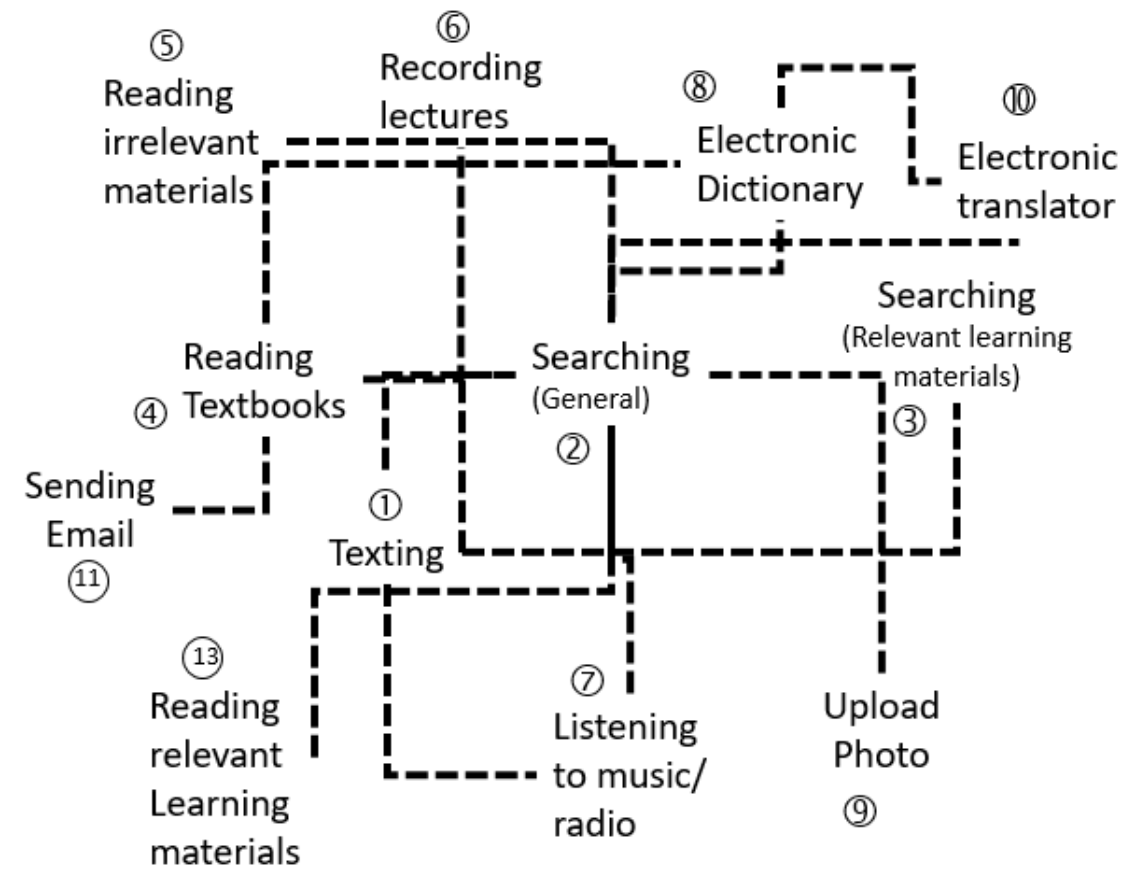

Fig. 1. Preservice teachers' multitasking behaviours map

was the negative effect of such a behaviour towards their learning performance. For example, Harman and Sato's [25] and Murphy and Manzanares's [5] studies have shown the negative impact of students' texting during class on their learning performance. One of the drivers of this negative effect was preservice teachers' reluctance to use smartphone to support their learning. The case was similar to the present study that preservice teachers were observed not to optimise their web activity to find materials relevant to their learning. Moreover, preservice teachers' reading activity did not seem to focus on the materials they should have comprehend.

\subsection{The effects of multitasking behaviours with smartphone on preservice teachers' learning}

In the survey, we asked the preservice teachers to write their opinion about the effect of multitasking behaviours on their learning. Preservice teachers' responses were both positive and negative. Those who perceived positive mentioned that multitasking behaviours benefited learning. At most, preservice teachers were shown to gain benefits from using multiple applications on their smartphones such as e-book reader, electronic dictionary, electronic translator and website browsers. Preservice teachers explained that while reading textbooks which was written in English from their smartphone application, they could access electronic dictionary at the same time to help them with difficult vocabularies. Some of them also acknowledged that they employed electronic translator application in their smartphone in order able to under- 
stand the book content. In addition, in many cases, preservice teachers mentioned that they made access to websites to search for more explanations about the topic they were learning. One of preservice teachers, Murni writes, "I could find more information from websites relevant to the topic I was reading on the electronic textbooks at the same time".

The data from the survey showed an interesting fact that such benefits from the incorporation of smartphone and preservice teachers' multitasking behaviour were promoted by teachers' instructional method in classroom. Rani, one of the preservice teachers, writes:

"My multitasking with smartphone particularly occurred due to my teachers' teaching method. They asked as to download the electronic reading textbooks and read it from our smartphone. In classroom discussion, they also encouraged us to find some more information from webpages related to topic the students were reading."

Other preservice teacher, Ryan, similarly writes:

"During a discussion session, our teachers often gave us a thought provoking question. When most of us were not able to find the answer to the question from the textbook, they required us to search for information from webpage on the internet."

In addition to the benefits of smartphone use and multitasking behaviours to facilitate reading and learning resources, we identified two other benefits: smartphone use and preservice teachers' multitasking behaviour had been the driver of preservice teachers' learning independence and motivation. We perceived that during our course our students (the preservice teachers) seemed to become more independent learners. In the reading activity for example, the preservice teachers were observed to do multiplied search on the internet in order to find certain information from the topic they were learning. In other situation, they also shared the information they had found from the internet and compared to others'. We noted some preservice teachers did texting among them during the classroom discussion, though information about the content of their text was not apparent to us.

Furthermore, preservice teachers perceived that multitasking behaviour had been "a refreshment" in preservice teachers' learning in classroom. Texting, uploading picture in Instagram, or made comment of Facebook seemed to be alterative solution to get rid of boredom during classroom learning which eventually recharge preservice teachers' motivation to learn. Findings from the survey support this claims showing that $28.57 \%$ mentioned the reasons they made access to their smartphone was particularly to get rid of boredom. Although $28.57 \%$ does not seem a high number of response and therefore statistically cannot be an evidence, we observed few students felt relaxed after their access to smartphone application.

Despite of the above benefits, findings from the survey showed that preservice teachers perceive negative effect of multitasking behaviours on their learning. The most cited argument was that multitasking was considered as a distraction of their learning focus. Amy, one of the preservice teachers writes: "It (multitasking behaviour) affects badly on my concentration during classroom learning. I have to split my focus into two: smartphone and my teachers' explanation." Lina, other preservice teacher write similar response, "It was quite often that I missed the teachers' explanation because I was busy searching for certain information on the net and the electron- 
ic textbooks." In other words, multitasking seems to evolve into distractive tasks which contributed negatively to preservice teachers' learning. This finding corresponds to earlier research suggesting the negative impact of on students' learning e.g. Burak [6], Junco and Cotton [12]

\section{Conclusion and Implication}

The incorporation of smartphone in our classroom practice was in purpose. Using smartphone in classroom learning was expectedly to facilitate reading activity and as learning resources for the preservice teachers. As recent development of smartphone has provided its users with a number of features and applications that allows them to carry out several activities with their smartphone simultaneously, it is thus, multitasking behaviours with smartphone among preservice teachers is inevitable. The findings of this study suggest that multitasking behaviours provides both positive and negative effects. Two prominent positive effects from multitasking behaviours are that they promote learning independence and as a motivation driver. While the negative effect of multitasking behaviour is mainly to its potential to distract preservice teachers' focus in learning.

Several strategies have been offered in literature to avoid negative impact of multitasking behaviour, among others multiple skill practice and the development of smartphone policy at schools, particularly in classroom [3]. In addition to these strategy, in reference to our classroom practice, the incorporation of smartphone in classroom practice, particularly in context of teacher education program (TEP), should come with careful preparation. In addition, teachers' pedagogical knowledge for the incorporation of mobile technology, teachers' ability to manage the classroom activity as well as appropriate instructional method are important aspects to consider. Finally, preservice teachers' texting among them and searching activity in class should be seen as their willingness to communicate and work with others. And, this should inspire the courses in TEP to promote cooperative and collaborative learning to the students, which in our past practice, was not really apparent.

\section{$5 \quad$ References}

[1] E. Wood, L. Zivcakova, P. Gentile, K. Archer, D. De Pasquale, and A. Nosko, 'Examining the impact of off-task multi-tasking with technology on real-time classroom learning', Comput. Educ., vol. 58, no. 1, pp. 365-374, 2012. https://doi.org/10.1016/j.comp edu.2011.08.029

[2] R. Junco, 'In-class multitasking and academic performance', Comput. Human Behav., vol. 28, no. 6, pp. 2236-2243, 2012. https://doi.org/10.1016/j.chb.2012.06.031

[3] Q. Chen and Z. Yan, 'Does multitasking with mobile phones affect learning? A review', Comput. Human Behav., vol. 54, pp. 34-42, 2016. https://doi.org/10.1016/j.chb.2015. 07.047

[4] A. B. Grinols and R. Rajesh, 'Multitasking with smartphones in the college classroom', Bus. Prof. Commun. Q., vol. 77, no. 1, pp. 89-95, 2014. https://doi.org/10.1177/23294906 $\underline{13515300}$ 
Paper-Smartphone Use and Multitasking Behaviour in a Teacher Education Program (TEP)

[5] E. Murphy and M. A. Manzanares, 'Instant messaging in a context of virtual schooling: balancing the affordances and challenges', EMI. Educ. Media Int., vol. 45, no. 1, pp. 4758, 2008. https://doi.org/10.1080/09523980701847180

[6] L. Burak, 'Multitasking in the university classroom', Int. J. Scholarsh. Teach. Learn., vol. 6, no. 2, p. 8, 2012. https://doi.org/10.20429/ijsotl.2012.060208

[7] E. Baran, 'A review of research on mobile learning in teacher education.', Educ. Technol. Soc., vol. 17, no. 4, pp. 17-32, 2014.

[8] S. Price, P. Davies, W. Farr, C. Jewitt, G. Roussos, and G. Sin, 'Fostering geospatial thinking in science education through a customisable smartphone application', Br. J. Educ. Technol., vol. 45, no. 1, pp. 160-170, 2014. https://doi.org/10.1111/bjet.12000

[9] S. N. Şad and Ö. Göktaş, 'Preservice teachers' perceptions about using mobile phones and laptops in education as mobile learning tools', Br. J. Educ. Technol., vol. 45, no. 4, pp. 606-618, 2014. https://doi.org/10.1111/bjet.12064

[10] P. Seppälä and H. Alamäki, 'Mobile learning in teacher training', J. Comput. Assist. Learn., vol. 19, no. 3, pp. 330-335, 2003. https://doi.org/10.1046/j.02664909.2003.00034.x

[11] O. Serin, 'Mobile learning perceptions of the prospective teachers (Turkish Republic of Northern Cyprus sampling)', TOJET Turkish Online J. Educ. Technol., vol. 11, no. 3, 2012.

[12] R. Junco and S. R. Cotten, 'No A 4 U: The relationship between multitasking and academic performance', Comput. Educ., vol. 59, no. 2, pp. 505-514, 2012. https://doi.org/10.1016/j.compedu.2011.12.023

[13] Y. Ellis, B. Daniels, and A. Jauregui, 'The effect of multitasking on the grade performance of business students', Res. High. Educ. J., vol. 8, p. 1, 2010.

[14] J. E. Puente, 'Examining the effects of distractive multitasking with peripheral computing in the classroom', Nova Southeastern University, 2017.

[15] N. Solihati and H. Mulyono, 'A Hybrid classroom instruction in second language teacher education (SLTE): A critical reflection of teacher educators', Int. J. Emerg. Technol. Learn., vol. 12, no. 5, pp. 169-180, 2017. https://doi.org/10.3991/ijet.v12i05.6989

[16] W. He, D. Gajski, G. Farkas, and M. Warschauer, 'Implementing flexible hybrid instruction in an electrical engineering course: The best of three worlds?', Comput. Educ., vol. 81, pp. 59-68, 2015. https://doi.org/10.1016/j.compedu.2014.09.005

[17] K. Bailey and S. Springer, 'Reflective teaching as innovation', in Innovation and change in English language education, K. Hyland and L. L. C. Wong, Eds. New York: Rutledge, 2013, pp. 106-122.

[18] T. S. C. Farrell, Reflective language teaching: From research to practice. London, New York: Continuum, 2007.

[19] T. S. C. Farrell, Promoting teacher reflection in second language education: A framework for TESOL professionals. New York: Routladge, 2015.

[20] J. C. Richards and T. S. C. Farrell, Professional development for language teachers: Strategies for teacher learning. New York: Cambirdge University Press, 2005. https://doi.org/10.1017/CBO9780511667237

[21] T. S. C. Farrell, 'Reflective practice as innovation in SLTE', in International perspective on English languge teacher education, T. S. C. Farrell, Ed. Palgrave Macmillan, 2015, pp. 193-200.

[22] F. Martinez, S. Taut, and K. Schaaf, 'Classroom observation for evaluating and improving teaching: An international perspective', Stud. Educ. Eval., vol. 49, pp. 15-29, 2016. https://doi.org/10.1016/j.stueduc.2016.03.002 
[23] C. R. Rayford, 'Reflective practice: The teacher in the mirror', Doctoral Thesis. University of Nevada, 2010.

[24] D. R. Tindell and R. W. Bohlander, 'The use and abuse of cell phones and text messaging in the classroom: A survey of college students', Coll. Teach., vol. 60, no. 1, pp. 1-9, 2012. https://doi.org/10.1080/87567555.2011.604802

[25] B. A. Harman and T. Sato, 'Cell phone use and grade point average among undergraduate university students', Coll. Stud. J., vol. 45, no. 3, p. 544, 2011.

\section{Authors}

Ade Hikmat is a professor on Indonesian Language Education at Faculty of Teacher Training and Pedagogy, University of Muhammadiyah, Prof. Dr Hamka (UHAMKA). His research interests include first language education, discourse analysis, language and literature, and teacher education.

Herri Mulyono is a lecturer at Faculty of Teacher Training and Pedagogy, University of Muhammadiyah Prof. Dr Hamka (UHAMKA). He is a director of Education Research Forum (ERF) at the University. Herri is currently a PhD candidate at University of York, UK with his doctoral research investigating the use of technology to enhance collaborative writing activity at secondary schools in Indonesia.

Article submitted 24 June 2017. Resubmitted 12 December 2017. Final acceptance 05 March 2018. Final version published as submitted by the authors . 